\title{
The efficacy of four miticides for the control of Acarapis woodi (Rennie) in a fall treatment program
}

\author{
CD Scott-Dupree *, GW Otis \\ University of Guelph, Department of Environmental Biology, Guelph, Ontario N1G 2W1, Canada
}

(Received 3 June 1991; accepted 3 December 1991)

\begin{abstract}
Summary - Four miticides in various formulations and concentrations were applied in a fall treatment program to honey bee colonies infested with Acarapis woodi. The miticides tested were menthol, Amitraz, fluvalinate (Apistan ${ }^{\circledR}$ ), and cymiazole (Apitol ${ }^{\circledR}$ ). None of the miticides significantly reduced mite prevalence in treated colonies relative to the control treatment. Additional studies should be undertaken in temperate climates to determine whether the efficacy of the miticides tested in this study can be improved by administering them at other time during the year or by adjusting dosages rates to improve their efficacy when applied to infested colonies during a fall management program.
\end{abstract}

Acarapis woodi / miticide / chemical control / efficacy

\section{INTRODUCTION}

The honey bee tracheal mite, Acarapis woodi (Rennie), is an internal parasite of the adult honey bee. Adult female mites enter the tracheae of young adult bees where they pierce the tracheal walls, feed on host hemolymph, and reproduce. Mite infestations are reported to reduce the longevity of adult bees (Bailey, 1958; Bailey and Lee, 1959; Giordani, 1962; Maki et al, 1986), reduce the total amount of spring brood in a colony (Wilson et al, 1990; Otis and Scott-Dupree, 1992) and increase colony mortality during the winter (Bailey, 1958, 1961; Bailey and Lee, 1959; Furgala et al, 1989). Furthermore, it has also been determined that mite preva- lence in honey bee colonies peaks in late winter before undergoing a substantial decline in late spring (Otis et al, 1988; ScottDupree and Otis, 1988). An up-to-date summary of $A$ woodi biology and their impact on honey bee colonies is provided by Kjer et al (1989). Until recently, there was disagreement over the potential impact of tracheal mites on the North American beekeeping industry (Bailey, 1985). Recent studies (Guzman-Novoa and ZozayaRubio, 1984; Maki et al, 1986; Eischen, 1987; Cox et al, 1988; Eischen et al, 1989a; Furgala et al, 1989; Moffett et al, 1989; Otis and Scott-Dupree, 1992) have shown that $A$ woodi is having a serious negative impact on beekeeping in Canada and the US.

\footnotetext{
* Correspondence and reprints
} 
With the exception of menthol and Amitraz in the United States, there are no other chemicals registered for use in the control of tracheal mites in colonies in either Canada or the US. Several miticides have been evaluated for use against the tracheal mite (Giavarini and Giordani, 1966; Eischen et al, 1986; Herbert et al, 1987, 1988; Cox et al, 1988; Eischen et al, 1988; Moffett et al, 1988, 1989; Eischen et al, 1989a, b) in the US. The objective of this project was to test the efficacy of 4 miticides on $A$ wood $i$ in a fall treatment program. The reasons why we chose to administer the miticides in the fall were: 1) Studies have shown that mite prevalence in honey bee colonies peaks during the late winter and then declines to negligible levels in the summer (Otis et al, 1988). We felt that treatment of tracheal mite infested colonies prior to this dramatic increase in mite prevalence may prevent colony mortality and other negative effects of mite infestation. 2), Miticides applied in the fall may be less likely to result in residues in honey crops.

\section{MATERIALS AND METHODS}

Four beeyards belonging to one beekeeper were randomly chosen for use in a fall miticide trial. On 7 September, 1988, it was determined that the apiaries had mean tracheal mite prevalence values of $20-25 \%$. The 4 beeyards were located in Orleans, Monroe and Genessee counties of New York. Four miticides in various formulations and concentrations were tested in a total of 10 treatments. The treatments tested have been listed below.

\section{Menthol}

Treatment 1: Natural Menthol Crystals (purchased from Mann Lake Supply, MN)

Treatment 2: Synthetic L-Menthol Pellets (Haarmann and Reimer, Division of Bayer (Canada) Inc)
For Treatments 1 and 2, one 50-g screened packet of menthol was placed over the bee cluster in the second brood chamber of each of the experimental colonies in these treatment categories. The packet containing natural or synthetic menthol remained on the colony for 1 month. The packets were not weighed upon their removal.

Amitraz: ( $\mathrm{N}^{\prime}-(2,4-d i m e t h y l p h e n y)-\mathrm{N}$ $<<2,4-d i m e t h y l p h e n y l) i m i n o>$ methyl $>-N$ -methylmethaniminamide); amitraz, Nor-Am Chemical Co)

Treatment 3: Amitraz EVA strips, $10 \%$ active ingredient (Al) per strip. One plastic strip impregnated with Amitraz was suspended between frames in the middle of the second brood chamber in each colony in this category.

Treatment 4: Amitraz Aerosol Spray, 10\% Al per colony per treatment. Amitraz was sprayed between all frames in the second brood chamber for a total of 10 seconds per colony. A second application was administered in the same manner 12 days after the first, as recommended by Nor-Am Chemical Co.

Apistan: (N-<2-chloro-4-(trifluoromethyl-phenyl>-D-valine(+)-a- cyano-(3phenoxyphenyl) methyl ester); fluvalinate, Zoecon Corp)

Treatment 5: Apistan Strips, 10\% Al per strip. Two plastic strips impregnated with Apistan were suspended between frames 3 and 4 , and 7 and 8 in the second brood chamber of all colonies in this category.

Treatment 6: Fluvalinate Fumigant Papers $25.2 \mathrm{mg} \mathrm{Al}$ per colony per treatment.

Treatment 7: Fluvalinate Fumigant Papers $50.4 \mathrm{mg} \mathrm{Al}$ per colony per treatment. One fumigant paper was lit, then was extinguished, and the smoldering paper was placed inside the colony through the bottom entrance. The papers were supported by a wooden clothes peg. The entrance was sealed for 30 minutes. A second treatment was administered 12 days later, as recommended by Zoecon Corp. 
Apitol: (2-<2,4-dimethylphenyl-imino<-3methyl-4-thiazoline-hydrochloride; $c y$ miazole, Ciba-Geigy Ltd)

Treatment 8: Concentration I, $0.35 \mathrm{mg} / \mathrm{ml} \mathrm{Al.}$ Cymiazole is a systemic and was administered to the bees in a sugar syrup feed solution (Eischen et al, 1989b). In this treatment $2.0 \mathrm{~g}$ of Apitol and $4.0 \mathrm{~g}$ of citric acid were dissolved in 2.25 I of a 2:1 sugar/water (by volume) solution and fed to each colony. Citric acid was added to prevent the rapid cystallization and improved the attractiveness of the medicated feed.

Treatment 9: Concentration $11,0.70 \mathrm{mg} / \mathrm{ml} \mathrm{Al}$. In this treatment $4.0 \mathrm{~g}$ of cymiazole and $4.0 \mathrm{~g}$ of citric acid were dissolved in 0.75 I of 2:1 sugar/ water (by volume) solution and fed to each of the colonies. In both treatments 8 and 9 , all the medicated feed was consumed by 9 November, 1988 and the empty feeders were removed.

\section{Control: Treatment 10}

Control colonies received no miticides during the study. Each treatment consisted of 11 experimental colonies resulting in a total of 110 colonies utilized in the study. All treatments were represented in each of the 4 apiaries.

The colonies utilized in the study were neither equalized or requeened because we wanted to study colonies that were under routine management as performed by the beekeeper. All colonies were overwintered in 2 brood chambers with adequate stores of honey and pollen for overwintering. Colonies were not provided with any supplemental feed or additional insulation. This is considered to be normal overwintering procedure for beekeepers in the region of New York where the study took place. Oxytetracycline hydrochloride (Terramycin 25) mixed with powdered sugar was applied to colonies in October 1988 and April 1989 at recommended dosage rates. No other drugs were administered.

The initial treatments of menthol, Amitraz and fluvalinate were administered on 8 October 1988. The second treatment of Amitraz Aerosol (Trt 4) and Fluvalinate Fumigant Papers (Trts 6 and 7), and the first treatment of Apitol (Trts 8 and 9) were administered on 20 October 1988.
The procedures used to administer the miticides to the colonies are described above. Menthol packets (Trt 1 and 2), Amitraz EVA strips ( $\operatorname{Tr} 3$ ) and Apistan strips (Trt 5) were removed from the colonies on 9 November, 1988.

Adult bees were collected from all study colonies on 8 October (ie, pre-treatment sample), 9 November and 21 April 1988-1989. Bees were collected using a small portable vacuum cleaner from the top of frames. For colonies with smaller populations, hives were opened and samples taken directly from the outer edge of the cluster of bees. Robinson et al (1986) determined that sampling location within the hive does not influence the mite prevalence values. Colony mortality was determined at the time of sampling. It was not possible to sample bees without some minor disturbance to colonies.

Samples usually contained $>100$ bees; few samples contained $<80$ and none had $<60$ bees. These samples were immediately placed in 190-ml plastic jars with $70 \%$ ethanol. The presence of mites was determined for approximately 100 bees in each sample unless that sample contained fewer bees. Thoracic disks were cut such that they contained the main tracheal trunks. Groups of $50+$ thoracic disks were incubated in $5 \% \mathrm{KOH}$ for 24 hours at $43^{\circ} \mathrm{C}$ (Delfinado-Baker, 1984). Each disk was inspected individually with a dissecting microscope at $40 x$ or $63 \mathrm{x}$ for the presence or absence of mites. If there was any doubt concerning the presence or numbers of mites, the tracheae were removed, mounted on a microscope slide, and viewed at $40 \times$ or $80 \times$ under a compound microscope.

Data were recorded in 3 ways, each providing different information on mite infestations within honey bee colonies: 1), Mite prevalence is the percentage of mite-infested honey bees in a sample (Margolis et al, 1982, "prevalence" (W) of Eischen, 1987). In addition, approximate mite infestation was ranked for each trachea examined. Rankings were: $1=<10$ mites at all stages of development; $2=11-20$ mites; $3=21-30$ mites; $4=31-40$ mites; $5=>40$ mites. 2 ), The sum of the ranks for the 2 tracheae of a bee provided a mite-load score. The mean mite-load score is determined by summing the mite-load scores for all bees in a sample and dividing by the total number of bees (both infested and uninfested) in the sample ("parasite load score" of Eischen 1987). 3), Finaliy, "tracheae-load scores" were calculated using the same ranking 
system developed for the determination of "mite-load scores". The mean tracheae-load score was calculated by summing the ranked scores for all bees in a sample and dividing by the number of mite-infested tracheae in the sample. Each method of recording data provides a different method of interpreting the mite infestation data and was a necessary component of data analysis because mortality of mites following treatment with miticides had to be determined indirectly from bees collected and stored in alcohol.

Mite prevalence data were analyzed using a 1-way analysis of variance (ANOVA) (BMDP General Linear Models Procedure) to compare the mean differences between the control treatment with each of the miticides for the sample intervals October-November, October-April, and November-April; and to determine potential differences between the 4 apiaries used in the study. The mite-load scores and tracheae-load scores were analyzed using ANOVA (BMDP General Mixed Model Procedure) comparing mean differences in the same manner as for the mite prevalence data. The probability of a type I error was set at $\alpha=0.05$.

\section{RESULTS}

The ANOVA indicated that there were no significant differences between the 4 apiar- ies used in the study $(P>0.5)$ and data were therefore pooled.

Mite prevalence values (table I) generally indicate a slight increase in mite infestation by November, but lower levels of mite infestation by April. Statistical analysis for all sample intervais determined that none of the miticides significantly reduced mite infestation levels in treated colonies relative to those in the control treatment (November to April: $P=0.7755$; October to April: $P=0.5470$; October to November: $P=0.1708$ ). Because this latter comparison approached significance, a LSD pairwise comparison of the control with each of the miticide treatments was performed for the October to November interval. This analysis indicated that 3 treatments (Natural Menthol (Trt 1): $P=0.1570$; Amitraz Aerosol (Trt 4): $P=0.1253$; Apitol Concentration II (Trt 9): $P=0.1876$ ) appeared to have marginal effects on $A$ woodi. The screened packets of menthol utilized in Treatments 1 and 2 were not weighed following removal on Day 30 . However, the amount of menthol contained in the screened packets on their removal was not

Table I. Mean mite prevalence for each miticide treatment and sample date.

\begin{tabular}{|c|c|c|c|c|}
\hline \multirow{2}{*}{$\begin{array}{c}\text { Treatment } \\
\text { No }\end{array}$} & \multirow[t]{2}{*}{ Miticide } & \multicolumn{3}{|c|}{ Mean mite prevalence $(\%) \pm S E$} \\
\hline & & $\begin{array}{l}\text { October } \\
\quad(n=11)\end{array}$ & $\begin{array}{l}\text { November } \\
(\mathrm{n}=11)\end{array}$ & $\begin{array}{c}\text { April } \\
(n=11)\end{array}$ \\
\hline 1 & Natural Menthol & $21.00 \pm 6.81$ & $20.64 \pm 6.59$ & $14.89 \pm 4.65$ \\
\hline 2 & Synthetic L-Menthol & $17.91 \pm 6.45$ & $17.18 \pm 7.17$ & $4.56 \pm 1.23$ \\
\hline 3 & Amitraz EVA Strips & $34.09 \pm 9.89$ & $36.70 \pm 12.29$ & $9.67 \pm 6.68$ \\
\hline 4 & Amitraz Aerosol & $14.90 \pm 5.93$ & $12.36 \pm 6.28$ & $4.50 \pm 1.80$ \\
\hline 5 & Fluvalinate Apistan Strips & $21.27 \pm 8.32$ & $27.64 \pm 9.04$ & $19.89 \pm 6.71$ \\
\hline 6 & $\begin{array}{l}\text { Fluvalinate Fumigant Papers } \\
25.2 \mathrm{mg} \mathrm{Al}\end{array}$ & $24.55 \pm 7.49$ & $31.82 \pm 9.55$ & $19.78 \pm 7.01$ \\
\hline 7 & $\begin{array}{l}\text { Fluvalinate Fumigant Papers } \\
50.4 \mathrm{mg} \mathrm{Al}\end{array}$ & $31.64 \pm 10.42$ & $37.18 \pm 12.10$ & $20.33 \pm 9.52$ \\
\hline 8 & Apitol Concentration I & $30.18 \pm 8.48$ & $40.82 \pm 11.10$ & $18.17 \pm 4.87$ \\
\hline 9 & Apitol Concentration II & $18.27 \pm 4.78$ & $14.82 \pm 6.04$ & $16.00 \pm 5.80$ \\
\hline 10 & Control & $37.36 \pm 9.72$ & $43.91 \pm 10.56$ & $28.33 \pm 9.94$ \\
\hline
\end{tabular}


noticeably less than the $50 \mathrm{~g}$ originally placed in them prior to application. During the period when menthol treatments were on colonies, from 8 October to 7 November 1988, there were only 2 days when the ambient temperature was above $18{ }^{\circ} \mathrm{C}$ (October 15 and $16,19.6^{\circ} \mathrm{C}$ and $18.7^{\circ} \mathrm{C}$ respectively).

An analysis of covariance indicated a highly significant relationship between mite-load score and mite prevalence. Mite prevalence was used as a covariate to adjust individual hives within a treatment to a common level of infestation and as a weighting factor to indicate the reliability of specific observations for both the mite-load score and tracheae-load score analysis. Mite-load scores for all treatments on each sample date are presented in table II. The results indicate that the change in miteload score for the control treatment, from November to April $(P=0.2552)$ and from October to April $(P=0.2047)$ is not significantly different from the change in miteload scores during the same time interval for any of the miticides tested.
For the October to November interval, the change in mite-load score for the control treatment was significantly different $(P=0.0471)$ from the change in mite-load scores during the same interval for the miticides tested. Despite the apparent differences, none of the 9 miticides was found to be significantly different from the control (table III). However, 3 miticide treatments exhibited marginal control of tracheal mites (Amitraz EVA Strips (Trt 3): $P=0.1096$; Fluvalinate Fumigant Papers $25.2 \mathrm{mg} \mathrm{Al}$ (Trt 6): $P=0.1096$; Apitol Concentration II (Trt 9): $P=0.1164$ ).

In the analysis of tracheae-load scores no significant interactions between miticide treatments and time for the intervals October to April, November to April, and October to November, were observed. The results indicate that the change in tracheae-load scores for the control treatment in all time intervals is not significantly different from the change in tracheae-load scores for any of the miticide treatments (October to April: $P=0.4478$; November to April: $P=0.4144$; October to November: $P=0.6891$ ).

Table II. Mean mite-load scores for each miticide treatment and sample data.

\begin{tabular}{|c|c|c|c|c|}
\hline \multirow{2}{*}{$\begin{array}{l}\text { Treatment } \\
\text { No }\end{array}$} & \multirow[t]{2}{*}{ Miticide } & \multicolumn{3}{|c|}{ Mean mite load scores \pm SE } \\
\hline & & $\begin{array}{l}\text { October } \\
(\mathrm{n}=11)\end{array}$ & $\begin{array}{l}\text { November } \\
(n=11)\end{array}$ & $\begin{array}{c}\text { April } \\
(n=11)\end{array}$ \\
\hline 1 & Natural Menthol & $1.30 \pm 0.46$ & $1.48 \pm 0.29$ & $1.72 \pm 0.24$ \\
\hline 2 & Synthetic L-Menthol & $1.49 \pm 0.14$ & $1.26 \pm 0.22$ & $1.40 \pm 0.24$ \\
\hline 3 & Amitraz EVA Strips & $1.49 \pm 0.26$ & $1.27 \pm 0.27$ & $1.16 \pm 0.42$ \\
\hline 4 & Amitraz Aerosol & $1.25 \pm 0.22$ & $1.25 \pm 0.28$ & $0.99 \pm 0.25$ \\
\hline 5 & Fluvalinate Apistan Strips & $1.09 \pm 0.18$ & $1.52 \pm 0.21$ & $1.63 \pm 0.27$ \\
\hline 6 & $\begin{array}{l}\text { Fluvalinate Fumigant Papers } \\
\qquad 25.2 \mathrm{mg} \mathrm{Al}\end{array}$ & $1.34 \pm 0.20$ & $1.40 \pm 0.19$ & $1.45 \pm 0.23$ \\
\hline 7 & $\begin{array}{l}\text { Fluvalinate Fumigant Papers } \\
\qquad 50.4 \mathrm{mg} \mathrm{Al}\end{array}$ & $1.50 \pm 0.19$ & $1.56 \pm 0.28$ & $1.39 \pm 0.34$ \\
\hline 8 & Apitol Concentration ! & $1.21 \pm 0.20$ & $1.53 \pm 0.19$ & $1.71 \pm 0.16$ \\
\hline 9 & Apitol Concentration II & $1.19 \pm 0.20$ & $0.97 \pm 0.24$ & $1.40 \pm 0.27$ \\
\hline 10 & Control & $1.64 \pm 0.11$ & $1.83 \pm 0.09$ & $1.51 \pm 0.30$ \\
\hline
\end{tabular}


Table III. $Z$ statistics for the change in the mean mite-load score for the control treatment compared to the change for any of the miticide treatments during the sample interval of October to November.

\begin{tabular}{clrc}
\hline $\begin{array}{c}\text { Treatment } \\
\text { No }\end{array}$ & Miticide & $Z$-value & $\begin{array}{c}\text { Appropriate } \\
P \text {-value }\end{array}$ \\
\hline & & & \\
1 & Natural Menthol & -0.41 & 0.6818 \\
2 & Synthetic L-Menthol & 0.26 & 0.7948 \\
3 & Amitraz EVA Strips & 1.60 & 0.1096 \\
4 & Amitraz Aerosol & -0.35 & 0.7264 \\
5 & Fluvalinate Apistan Strips & -1.12 & 0.2628 \\
6 & Fluvalinate Fumigant Papers & 1.60 & 0.1096 \\
7 & 25.2 mg Al & & \\
8 & Fluvalinate Fumigant Papers 50.4 mg Al & 0.17 & 0.8650 \\
9 & Apitol Concentration I & 0.82 & 0.4122 \\
& Apitol Concentration II & 1.57 & 0.1164 \\
\hline
\end{tabular}

\section{DISCUSSION}

This study has shown that the miticides tested had no significant effect in reducing tracheal mite levels in honey bee colonies when administered in a fall treatment program in New York state. Several of the miticides (Natural Menthol (Trt 1); Amitraz EVA Strips (Trt 3); Amitraz Aerosol (Trt 4); Fluvalinate Fumigant Papers -25.2 mg Al (Trt 6); and Apitol Concentration II (Trt 9) exhibited marginal control of $A$ woodi and therefore warrant additional testing to determine whether their efficacy improves when administered to colonies at other times throughout the year in New York state.

Relatively cool temperature conditions experienced during the fall and winter of 1988 in New York state are probably responsible for the ineffectiveness of both natural and synthetic menthol in this study. Researchers involved in other menthol trials have suggested that high temperatures $\left(>20^{\circ} \mathrm{C}\right.$ ) and strong colonies are necessary to initiate menthol vaporization and thereby provide effective control against honey bee tracheal mites (Cox et al, 1988; Herbert et al, 1988; Moffett et al, 1989; Wilson et al, 1990). These suggested requirements for optimal vaporization of menthol in colonies indicate that the application of this miticide may be limited to a late spring treatment program in New York state and other north temperate regions.

Although our results indicated marginal control of $A$ woodi by Amitraz Aerosol (Trt 4) these findings suggest that this miticide formulation has potential as a tracheal mite control product. In this context, the results are supportive of other studies (Moffett et al, 1988; Moffett et al, unpublished data; HCromroy, personal communication) which determined that Amitraz aerosol formulation provided excellent control of $A$ woodi. Moffett et al (unpublished data) tested the Amitraz aerosol formulation in a fall treatment program in Nebraska. In regard to season of miticide application and climatic conditions their experimental set up was similar to ours. However, in contradiction to their findings, we did not obtain significant control with the Amitraz aerosol formulation. We have no explanation for 
this result. Cromroy (unpublished data) found low but significant reductions of $A$ woodi in moderately infested colonies ( $\leq$ $55 \%$ mite prevalence) treated with Amitraz EVA Strips $(10 \% \mathrm{Al})$. However, in his study, 2 strips were placed between frames in a single brood chamber setup. Our study involved the placement of a single strip between frames in 2-brood chamber setup. The difference in the miticide dosage between these studies may account for the poor control of $A$ woodi with Amitraz EVA Strips observed in the New York state miticide trials.

Fluvalinate is effective against Varroa jacobsoni as a contact miticide. R Borneck (personal communication) indicated that fluvalinate may also control $A$ woodi based on the results of his observations of miteinfested colonies in France. In support of his observations, our results indicate marginal control of $\boldsymbol{A}$ woodi with Fluvalinate Fumigant Papers 25.2 mg (Trt 6). A gaseous formulation such as this could potentially contact tracheal mites while in the bee's tracheae. Problems were encountered in this study with inconsistent burning of the fumigant papers which probably affected its efficacy against $A$ woodi.

Cymiazole (Apito ${ }^{\circledR}$ ) has proven to be effective against honey bee tracheal mites (Eischen et al, 1988, 1989b). In this study, analysis of both mite prevalence and miteload scores indicate marginal control of A woodi by Apitol Concentration II (Trt 9).

Our fall application of medicated feed reduced the length of time available for the bees to prepare the feed prior to the onset of winter. Despite the lateness in applying Apitol to the colonies, the bees were able to store all of the medicated feed provided to them. Eischen et al (1989b) suggest that time of miticide application and techniques which foster consumption of treated syrup would enhance the efficacy of cymiazole (Apitol ${ }^{\circledR}$ ).
In summary, we feel that additional studies should be undertaken in cool temperate climates to determine whether the efficacy of the miticides tested in this study can be improved by administering them at other times during the year and at different dosage rates.

\section{ACKNOWLEDGMENTS}

We appreciate the assistance of D Ryan, from the Ashton Statistical Laboratory, Department of Mathematics and Statistics at the University of Guelph, for his assistance in the statistical analysis of data; Jim, Ed and Judy Doan for providing colonies, apiaries and assistance which were integral components of this study; T Welsh, P Kelly, R Nauta, B Dawicke and L Kukoly for their assistance in all technical aspects of the project. We extend our gratitude to Haarmann and Reimer (Division of Bayer (Canada) Inc), Nor-Am Chemical Co, Zoecon Corp, and Ciba-Geigy Ltd for the contribution of products and financial support for the study. Finally, we would like to thank the Ontario Beekeeper's Association for their support in obtaining an Ontario Ministry of Agriculture and Food grant which provided a major portion of the funding for this study.

Résumé - Efficacité de quatre acaricides vis-à-vis d'Acarapis woodi Rennie dans le cadre d'un programme de traitement d'automne. Au cours de l'automne 1988, 4 acaricides ont été testés sur des colonies d'abeilles dans le Nord de l'état de New York, à diverses concentrations et avec des formulations variées. Les 10 traitements appliqués étaient les suivants : 1 : menthol naturel; 2: L-menthol de synthèse; 3: bandelettes d'Amitraze EVA (10\% de matière active (MA)); 4: Amitraze en aérosol (10\% MA); 5 : lanière Apistan $(10 \%$ de MA fluvalinate); 6 : tickets fumigènes au fluvalinate $(25,2 \mathrm{ml} \mathrm{MA}) ; 7$ : tickets fumigènes au fluvalinate $(50,4 \mathrm{mg} \mathrm{MA})$; 8 : Apitol en concentration I $(0,35 \mathrm{mg} / \mathrm{ml}$ MA cymiazo- 
le); 9: Apitol en concentration II $(0,70 \mathrm{mg} /$ $\mathrm{ml} M A$ cymiazole) et 10: témoin (colonies non traitées). Chaque traitement a été appliqué à 11 colonies, l'expérimentation comptant donc 110 colonies.

Les abeilles adultes ont été récoltées dans toutes les colonies le 8 octobre (échantillonnage pré-traitement), le 9 novembre 1988 et le 21 avril 1989. Les analyses statistiques ont été faites à partir des données suivantes : fréquence et degré d'infestation des abeilles, degré d'infestation des trachées. Chaque méthode d'analyse des données fournissait une approche différente pour interpréter les données d'infestation, qui était nécessaire car il fallait déterminer les changements de populations d'acariens sur des abeilles prélevées après traitement et conservées à l'alcool.

Aucun des traitements acaricides n'a réduit de façon significative la fréquence de l'acarien par rapport aux témoins. Des résultats semblables ont été trouvés en ce qui concerne le degré d'infestation des abeilles et des trachées. On trouve pourtant une fréquence d'infestation légèrement réduite si l'on compare 2 à 2 (test LSD) le groupe témoin et les traitements $n^{\circ} 1(P=0,1570), n^{\circ} 4(P=0,1253)$ et $n^{\circ} 9(P=0,1876)$. De même, le degré d'infestation des abeilles est légèrement (mais non significativement) réduit si l'on compare le témoin et les traitements $n^{\circ} 3$ $(P=0,1096), n^{\circ} 6(P=0,1096)$ et $n^{\circ} 9(P$ $=0,1164$ ).

Nous estimons que des études complémentaires à réaliser en climat tempéré sont nécessaires pour déterminer si on peut améliorer l'efficacité des acaricides testés ici en les administrant à d'autres périodes de l'année ou à des doses différentes pour un traitement d'automne.

Acarapis woodi / acaricide / lutte chimique / efficacité
Zusammenfassung - Die Wirksamkeit von vier Milbenmitteln zur Kontrolle von Acarapis woodi (Rennie) in einem Programm für die Herbstbehandlung. Im Herbst 1988 wurden im nördlichen Teil des Staates New York vier Milbenmittel in verschiedener Formulation und Konzentration an mit Tracheenmilben befallenen Völkern geprüft. Folgende Präparate und Anwendungen wurden geprüft:

1), Natürliches Menthol; 2), Synthetisches L-Menthol; 3), Amitraz EVA-Streifen (10\% aktive Substanz); 4), Amitraz AerosolSpray (10\% aktive Substanz); 5), Apistan Streifen (10\% Fluvalinat); 6), FluvalinatRäucherstreifen (25,2 mg); 7), FluvalinatRäucherstreifen (50,4 mg); 8), Apitol, Konzentration I (0,35 mg/ml Cymiazol); 9), Apitol, Konzentration II $(0,70 \mathrm{mg} / \mathrm{ml}$ Cymiazol); 10), Kontrolle (unbehandelte Völker). Jede von diesen 10 Behandlungsgruppen bestand aus 11 Völkern, der Versuch umfaßte also 110 Völker.

Von allen Versuchsvölkern wurden Bienenproben am 8 Oktober (Probe vor Versuchsbeginn), 5 November und am $21 \mathrm{~T}$ April 1988/1989 entnommen. Zur statistischen Analyse wurden Daten über Befallshäufigkeit und -grad und über den Befallsgrad der Tracheen gesammelt. Jede Methode der Analyse der Daten liefert einen unterschiedlichen Ansatz zur Interpretation der Befallsdaten und bildet eine notwendige Prozedur, weil die Veränderungen der Milbenpopulation aufgrund von Bienen bestimmt werden mußten, die nach der Behandlung gesammelt und in Alkohol aufbewahrt wurden.

Keines der Behandlungsverfahren führte zu einer signifikanten Reduzierung der Befalishäufigkeit mit Tracheenmilben bei den Versuchsvölkern im Vergleich zu den Kontrollen. Ähnliche Ergebnisse im Vergleich zu den Kontrollen ergaben sich für jeden der Versuchsansätze beim Befallsgrad der Einzelbiene und der Tra- 
cheen. Es zeigte sich jedoch eine geringfügige Verminderung des Befalls mit Acarapis woodi bei paarweisem Vergleich der Befallshäufigkeit der Kontrollgruppe mit folgenden Behandlungsansätzen: Behandlung 1) natürliches Menthol $(P=0,1570)$; Behandlung 4) Amitraz Aerosol ( $P=$ 0,1253 ); Behandlung 9) Apitol, Konzentration II $(P=0,1876)$. Auch beim Befallsgrad zeigten drei Mittel eine marginale, nicht signifikante Wirkung im Vergleich zur Kontrolle: Behandlung 3) Amitraz EVA Streifen $(P=0,1095)$; Behandlung 6$)$ Fluvalinat Räucherstreifen $(P=0,1096)$; Behandlung 9) Apitol Konzentration II ( $P=0,1164)$.

Wir haben das Gefühl, daß zusätzliche Untersuchungen in gemäBigtem Klima unternommen werden sollten, um festzustellen, ob die Wirksamkeit der in dieser Studie geprüften Mittel entweder duch Anwendung zu anderer Jahreszeit oder durch eine andere Dosierung während der Herbstbehandlung verbessert werden kann.

Acarapis woodi / Milbenmittel / chemische Kontrolle / Wirksamkeit

\section{REFERENCES}

Bailey $L(1958)$ The epidemiology of the infestation of the honey bee, Apis mellifera L, by the mite Acarapis woodi Rennie and the mortality of infested bees. Parasitology 48, 493-506

Bailey $L$ (1961) The natural incidence of Acarapis woodi (Rennie) and the winter mortality of honey bee colonies. Bee World 42, 96-100

Bailey L (1985) Acarapis woodi: a modern appraisal. Bee World 66, 99-104

Bailey L, Lee DC (1959) The effect of infestation with Acarapis woodi (Rennie) on the mortality of honey bees. J Insect Pathol 1, 15-24

Cox RL, Moffett JO, Ellis M, Wilson WT (1988) Long-term beneficial effects of menthol treatment on honey bee colonies infested with tracheal mites Acarapis woodi. Proc 3rd Am
Bee Res Conf, Weslaco, TX. Am Bee J 128 (12), 801

Delfinado-Baker M (1984) Acarapis woodi in the United States. Am Bee J 124, 805-806

Eischen FA (1987) Overwintering performance of honey bee colonies heavily infested with Acarapis woodi (Rennie). Apidologie 18, 293-304

Eischen FA, Pettis JS, Dietz A (1986) Prevention of Acarapis woodi infestation in queen honey bees with Amitraz. Am Bee J 126, 498-500

Eischen FA, Vergara C, Dietz A, CardosoTamez D (1988) Cymiazole, a systemic acaracide that controls Acarapis woodi (Rennie) infesting honey bees. I. Laboratory tests. Apidologie 19(4), 367-376

Eischen FA, Cardoso-Tamez D, Wilson WT, Dietz A (1989a) Honey production of honey bee colonies infested with Acarapis woodi (Rennie). Apidologie 20, 1-8

Eischen FA, Cardoso-Tamez D, Dietz A, Ware GO (1989b) Cymiazole, a systemic acaracide that controls Acarapis woodi (Rennie) infesting honey bees. II. An apiary test. Apidologie 20(1), 41-51

Furgala B, Duff S, Aboulfaraj S, Ragsdale D, Hyser $R$ (1989) Some effects of the honey bee tracheal mite (Acarapis woodi Rennie) on non-migratory, wintering honey bee (Apis mellifera $L$ ) colonies in east central Minnesota. Am Bee J 129, 195-197

Giavarini I, Giordani G (1966) Study of acarine disease of honey bee. Final technical report Nazionale di Apicoltura Bologna, Italy, $51 \mathrm{p}$

Giordani G (1962) Richerche di laboratorio sur Acarapis woodi Rennie agente dell'acariosi des abeilles (Apis mellifera L). Note 1. Bull Apic Inform 5, 33-51

Guzman-Novoa E, Zozaya-Rubio A (1984) The effects of chemotherapy on the level of infestation and production of honey in colonies of honey bees with acariosis. Am Bee $J 124$, 669-672

Herbert EW, Shimanuki $H$, Matthenius JC (1987) The effect of two candidate compounds on Acarapis woodi in New Jersey. Am Bee J 127, 776-778

Herbert EW Jr, Shimanuki H, Matthenius JC Jr (1988) An evaluation of menthol placement in hives of honey bees for the control of Acarapis woodi. Am Bee J 128(3), 185-187 
Kjer KM, Ragsdale DW, Furgala B (1989) A retrospective and prospective overview of the honey bee tracheal mite, Acarapis woodi R. Am Bee J 129, 25-28, 112-115

Maki DL, Wilson WT, Cox RL (1986) Infestation by Acarapis woodi and its effect on honey bee longevity in laboratory cage studies. $A m$ Bee J 126, 832

Margolis L, Esch GW, Holmes JC, Kuris AM, Schad GA (1982) The use of ecological terms in parasitology (Report of an ad hoc committee of the American Society of Parasitologists). J Parasitol 68, 131-133

Moffett JO, Wilson WT, Cox RL, Ellis M (1988) Four formulations of Amitraz reduce tracheal mites, Acarapis woodi, populations in honey bees. Proc 3rd Am Bee Res Conf, Weslaco, TX. Am Bee J 128(12), 805-806

Moffett JO, Cox RL, Ellis M, Riviera R, Wilson WT, Cardoso-Tamez D, Vargas-C J (1989) Menthol reduces winter population of tracheal mites, Acarapis woodi in honey bees from Mexico and Nebraska. Southwest Ento$\mathrm{mol} 14(1), 57-65$
Otis GW, Bath JB, Randall DL, Grant GM (1988) Studies of the honey bee tracheal mite (Acarapis woodi) (Acari: Tarsonemidae) during winter. Can J Zool 66, 2122-2127

Otis GW, Scott-Dupree CD (1992) Effects of tracheal mites (Acarapis woodi (Rennie)) on overwintered colonies of honey bees (Apis mellifera $\mathrm{L}$ ) in New York. $J$ Econ Entomo195 (1) $40-46$

Robinson FA, Thel KL, Littell RC, Linda SB (1986) Sampling apiaries for honey bee tracheal mites (Acarapis woodi Rennie): effects of bee age and colony infestation. Am Bee $J$ 126, 193-195

Scott-Dupree C, Otis G (1988) Parasitic mites of honey bees: to be or not to bee. Highlights Agric Res Ont 11, 24-28

Wilson WT, Cox RL, Moffett JO, Ellis M (1990) Improved survival of honey bee (Apis mellife$\mathrm{ra} \mathrm{L}$ ) colonies from long-term supression of tracheal mites (Acarapis woodi Rennie) with menthol. BeeScience 1(1), 48-54 